\title{
FUNCTIONING OF THE SYSTEM OF LOCAL AGRICULTURAL MARKETS: INSTITUTIONAL ASPECTS
}

\author{
Yurij PRUDNIKOV 1 \\ Zhytomyr National Agroecological University, Ukraine
}

\begin{abstract}
The purpose of this article is the generalization and systematisation of features of modern institutional support for functioning and development of a system of local agricultural markets. The methodology of research is formed on the basis of systematic approach to the studying socio-economic phenomena and processes that are taking place in a process of functioning and development of the system of local agricultural markets. Research results - based on the system analysis there are substantiated features of functioning and development of the system of local agricultural markets from the point of view of its institutional support. The stated is done with the purpose of determination of practicability, goal orientation, volumes, purpose and tasks of government intervention into the process of functioning and development of the system of local agricultural markets. Applying a general scheme of system analysis to the system of management of local agricultural markets and taking into account that the management system consists of two subsystems - management and controlled, in the context of this research there is made characteristics of the system in the form of answers to a specified list of questions. The essence of developed theoretical and methodological approach lies in the development of legitimate answers to four key questions peculiar and relevantly placed for each stage of research: 1) determination of elements of internal and external environments, which are included to the system of local agricultural markets; 2) characteristics of relations and connections among revealed system elements; 3 ) a process of functioning of the system of local agricultural markets as itself; 4) features of development of the system of local agricultural markets. Developed measures of regulatory nature aimed at overcoming identified disadvantages and development of the system of local agricultural markets are directed to the satisfaction of needs of target consumers of agricultural production and increase of quality product homogeneity within the commercial batch; increase of efficiency of agricultural production sales by direct manufacturers, formation of logistic system; reduction in prices' volatility; complex solution of a problem of development of infrastructural component of the system of markets, trading platform network expansion, prevention of misuse of market power, countermeasures for collusion of intermediate sellers and overcoming barriers that obstruct direct manufacturers to enter the markets of agricultural production, increase efficiency of a whole complex of the state regulations. Practical importance of the research results consists in the fact that the formed theoretical and methodological foundations of system analysis of the functioning and development of the system of local agricultural markets from the point of view of its institutional support will make possible its efficient functioning and development.
\end{abstract}

Key words: local markets, system of local markets, agricultural production, institutional support, institutions.

JEL Classification: B15, A11, 013

\section{Introduction}

Agricultural production sales by entities are carried out within institutional limits of structures, which in economic sense are traditionally considered as markets. In the context a taking into account a territorial aspect it is referred to the local agricultural markets. A totality of local markets from the point of view of national economy management is considered as a system of interrelated elements, which coherent functioning ensures the result that exceeds the sum of results of functioning of single markets (Belyaev, 2012; Dubrovin, Belov, 2011). Such a system effect or, in other words, a manifestation of emergence is determined by many causes. Local agricultural markets in a wide sense are poly production with a possible interchange for a consumer of one commodity item by another, which determines a correlated change in price (Stupnikova, 2013).

Moreover, mono production local markets have flexible enough, practically conventional territorial boundaries, which fluctuations will be under the influence of transportation cost, information price, 
as well as due to certain non-economic factors. A dynamics of market area requires their studying only as an integral aggregate. And, finally, only in an aggregate the local agricultural markets can provide achievement of a certain level of food security of the whole country, determine conditions of renewal of agricultural production and identify a status of the country as a net exporter or net importer of agricultural production by a certain commodity item. All mentioned above testifies a relevance of using system methodology in the process of substantiation of institutional support and identification of objectives, tasks and tools of local agricultural markets' regulation.

\section{Methodological essence of system analysis of local agricultural markets}

The purpose of functioning of local markets is the balance of agricultural production's demand and supply, minimization of transactional costs and risks in the interaction of market agents as well as establishment of effective distribution of "rent" as the difference between product realization price for ultimate customer and expenses for this production by agricultural manufacturer. Criteria of this goal's achievement should be food security of the country and growth of profitability of agricultural production. At the same time, using systematic approach requires some specifications in formulations.

System analysis envisages three aspects of the system research - substrate aspect, aspect of functioning and aspect of development. Applying a general scheme of system analysis to the system of management of local agricultural markets and taking into account that the management system consists of two subsystems - management and controlled, in the context of this research there is made characteristics of the studied system in the form of answers to a specified list of questions. This list should be considered as a methodology of system analysis of sectorallocal, regional or national markets in the context of determining the appropriateness, volumes, purpose, tasks and directions of government intervention in their functioning.

\section{Identification of elements included in the system of local agricultural markets}

The first question to be answered when studying the system of local agricultural markets is the determination of elements, which it includes. Characteristics of the system from the point of view of substrate require a description of the system elements, relations between them and ties where these relations are manifesting. In the controlled subsystem these element are obviously agricultural production, which serves as a subject of an agreement, and turnover assets, which are necessary for tangible agreements. These assets can be grouped according to the sphere of application, namely, assets of trading platforms, assets of transport, logistics, informational infrastructures and infrastructure of quality control sphere. An important asset that has a non-material form but participates in the functioning of local markets and ensures decrease in transactional costs of market agreements is a social capital of these agreements' parties. A question concerning the possibility of the state influence on social capital is controversial enough, depends on an interpretation of the category of social capital. If to suppose that there is no possibility to influence on social capital, it should be considered as an element of environment. Nonmaterialized but important elements of the system of local agricultural markets are prices for various groups of production, and also prices for the use of turnover assets.

There is no doubt that the system elements are active participants - entities that are under the managerial influence or are able to influence by themselves. We include to the controlled subsystem the following economic entities: agricultural manufacturers business of various legal organizational forms; buyers of production who can belong to different categories: citizens - ultimate consumers of agricultural production; processing companies, which buy raw materials from direct manufacturers and intend to sell agricultural production as food after significant processing or some post-harvesting (sorting, washing, packing); intermediate sellers who contemplate to sell the production in more outlying regions without any processing or post-harvesting; intermediate sellers who want to sell the production after a keeping period in special storage areas without any changes in the production's quality. As a result of combination of decisions of all buyers and sellers, such elements of the system of local agricultural markets are formed as demand and supply.

Besides the mentioned subjects, the system of local agricultural markets also includes infrastructural organizations possessing technical assets, which ensure agricultural production turnover: organizations that make the production quality check, transportation providers, enterprises that provide informational services, services for production storage, as well as central units of contracts' execution, which possess trading platforms.

When implementing contracts between actors in local agricultural markets, contracts -agreements in written or oral form - are executed. A contract should be also considered as an element of the system of local markets.

The state also serves as an element of this system: as the owner of assets of public use (transport network, for example) and as an arbiter who control observance of rules. The state participates in the organization of agreement and ensures self-organization of the local markets' system. The state can not only control 
observance of rules, but also set them, serving as an element of environment that will be explained below.

Buyers as well as sellers can act in local markets as individual independent entities or as a part of certain associations. The latter should be considered as elements of management subsystem $t$ together with bodies of state, regional and local government.

Based on data of the official website of the Ministry of Agrarian Policy and Food of Ukraine, institutions, which operate at the state level and should be included to the system of local agricultural markets, are determined. Such institutions are: the Ministry of Agrarian Policy and Food of Ukraine, in particular, the Department of Strategy and Economic Development - as the main element of management subsystem; State Agriculture Inspection of Ukraine (a procedure of the Inspection's liquidation is started from December 2015 onwards), the Agrarian Fund of Ukraine SSBI (starting from December 2015 a question about liquidation of the institution is bringing up) and the Agrarian Fund PJSC in the part of public purchases and interventions made by them; the State Veterinary and Phytosanitary Service of Ukraine, as well as the State Service of Ukraine on Food Safety and Consumer Protection - in the part of control over the quality of agricultural production, which get to the market turnover. An important place in the formation of the system of local agricultural markets is also taken by the State Service of Ukraine for Geodesy, Cartography and Cadastre in the part concerning the procedure of allocation of territories for building trading areas and other elements of infrastructure of the system of local markets. At the regional level, elements of the management subsystem of the local agricultural markets are general departments of agro-industrial development of regions, and also departments of agro-industrial development within district state administrations.

As a result of analysis of regulations on structural subdivisions of the Ministry of Agrarian Policy and Food of Ukraine, in the context of solving the issue of improving the organization of local agricultural markets by means of optimization of state influence on the system of these markets, it is determined that the main element of management subsystem of the system of local agricultural markets is the Department of Strategy and Economic Development. The elements, which can take up managerial influence, are other state institutions and immediate economic entities: sellers, buyers, intermediate sellers and infrastructural organizations -

Table 1

Elements of internal and external environment of the system of local agricultural markets

\begin{tabular}{|c|c|}
\hline Elements of internal environment & Elements of external environment \\
\hline $\begin{array}{l}\text { Materialized: } \\
\text { Agricultural production } \\
\text { Assets of sphere of circulation } \\
\text { Demand } \\
\text { Supply } \\
\text { Agreement } \\
\text { Non-materialized: } \\
\text { Services of assets of sphere of circulation } \\
\text { Prices for agricultural production } \\
\text { Prices for use of assets of circulation sphere } \\
\text { Social capital of parties of agreements } \\
\text { Elements of controlled subsystem - subjects, which take up managerial influence: } \\
\text { Sellers - producers } \\
\text { Buyers - ultimate consumers, } \\
\text { Buyers - processing companies } \\
\text { Buyers - intermediate sellers who resell after temporary storage } \\
\text { Infrastructural organization - transport, keepers, quality controller, informational } \\
\text { Elements of management subsystem - subjects, which exert managerial influence: } \\
\text { Ministry of Agrarian Policy and Food of Ukraine } \\
\text { Department of Strategy and Economic Development } \\
\text { State Agriculture Inspection of Ukraine } \\
\text { Agrarian Fund of Ukraine SSBI } \\
\text { Agrarian Fund PJSC } \\
\text { State Service of Ukraine on Food Safety and Consumer Protection } \\
\text { State Veterinary and Phytosanitary Service of Ukraine } \\
\text { State Service of Ukraine for Geodesy, Cartography and Cadastre } \\
\text { General departments of agro-industrial development of regions } \\
\text { Departments of agro-industrial development within district state administrations } \\
\text { Sellers associations } \\
\text { Buyers associations }\end{array}$ & $\begin{array}{l}\text { Laws of Ukraine: } \\
\text { "On basic foundations of state agrarian policy } \\
\text { until 2020" } \\
\text { "On State Support of Agriculture of Ukraine" } \\
\text { "On Wholesale Markets of Agricultural } \\
\text { Production" } \\
\text { Other regulations: } \\
\text { "Single and Comprehensive Strategy and } \\
\text { Action Plan for Agriculture and Rural } \\
\text { Development in Ukraine for 2015-2020" } \\
\text { General plans for territories' development } \\
\text { Independent factors of market conjuncture: } \\
\text { Price performance of the world and national } \\
\text { agricultural markets } \\
\text { State of financial markets }\end{array}$ \\
\hline
\end{tabular}

Source: own research 
owners of technical assets in the sphere of circulation. It should be noted that the analysis of regulations allows considering the Department of Strategy and Economic Development as the most important element of the management subsystem in name only. Real importance of each element can be determined only after the determination of ties and relations among them.

Within the first question there also should be defined conventional borders of the studied system, i.e. determined what has to be considered as external environment regarding this system. It follows that the environment formed by existent legal norms, proper acts of the state and regional levels approved by the state and regional programs of agrarian sector development, such as "Single and Comprehensive Strategy and Action Plan for Agriculture and Rural Development in Ukraine for 2015-2020", is considered as external in relation to the system of local agricultural markets (The only comprehensive strategy and action of plan for the development of agriculture and rural areas in Ukraine for 2015-2020, 2015).

In Ukraine, there is a set of special laws, which purpose is the institutionalization of relations between the state and other subjects of the sector of agro-industrial production, in particular, in the field of operation of agricultural markets. One of these laws if the Law "On State Support of Agriculture of Ukraine” (About State Support of Agriculture of Ukraine, 2004) and "On Wholesale Markets of Agricultural Production” (About wholesale markets of agricultural products: the Law of Ukraine, 2009). Beside laws and regulations, external environment of the system of local agricultural markets is also determined by price performance of the world and national agricultural markets, state of financial markets and general plan for appropriate territories' development. A structure of elements of internal and external environment of the system of local agricultural markets is shown in Table 1.

\section{Characteristics of relations among elements of the system of local agricultural markets}

Another question of research of the system of local agricultural markets concerns the characteristics of relations among revealed elements of the system. Among the elements of the system the following relations exist: competition (among subjects-buyers and subjects-sellers), purchase and sale (among subjects on agricultural production or services of technical assets), distribution (among subjects concerning extent of remuneration), belonging (among subjects and other impersonal system elements - assets and production), correlation of volumes (between demand and supply during the price assessment), concordance and coordination (within associations), regulation and control (among state institutions and other subjects). The relations are realized in material form, in form of non-material services, which accompany the flow of material substance, in the form of flow of funds and information, as well as form of compulsion, which can be implemented only by governmental authorities.

At this stage of analysis it is necessary to determine whether the Department of Strategy and Economic Development has relations (in any of the mentioned forms) with the system elements that take up managerial influence. As it follows from the Regulation on Department (Regulation on Department of Strategy and Economic Development of Ministry of Agrarian Policy and Food of Ukraine, 2016), the most its important tasks are related to providing other governmental authorities with information for decisionmaking, in particular, preparation of projects of law and regulations, development of proposals concerning lines of development of AIC and introduction of mechanisms for the development of agrarian economy, ensuring methodical unity in forecasting branches' development, analysis of statistical key figures, conducting price survey, addition of balances of demand and supply, preparation of analytical materials and so on. The most effective regulations are used by the Department in the field of metrology and standardization as well as in the field of public procurement.

\section{Functioning of the system of local agricultural markets}

The third question concerns functioning of the system of local agricultural markets. An aspect of the system functioning is revealing through the determination of the place, role and functioning of elements in the system, as well as highlighting quality of relations. This allows characterising the system in terms of sustainability, balance, homeostasis and self-organization (Tsvetkova, 2010). As we consider relations among economic entities by using market pattern, thus their functions are functions of buyer or seller.

Disadvantages in the execution of functions of the main elements of the local markets' system - seller, buyer and market price - are caused by imperfect execution of functions of auxiliary (infrastructural) market participants. Functions of entities, which belong to the market infrastructure, consist of providing appropriate services in sufficient volumes, which allows sustaining prices for these services at the moderate level and meeting the demands of sellers and buyers of agricultural products for these services. In this regard, infrastructural agents should have appropriate assets in sufficient volumes: transport organizations must have transport vehicles of different cargo-carrying capacities, with cooling agents (for animal production), immune to moisture (for plant products) etc.; organization, which store agricultural production, must have proper storages for grain crops, fruit and vegetables; organizations, which check the quality of production, must have necessary 
measurement instrumentation and be certified by the Department of Strategy and Economic Development; news agencies must have various media means - printed and online media; mediatory agents can perform their function if they have high-developed entrepreneurial skills and readiness to take risks.

Insufficient proposition of services of technical assets determines their outrageous price increase, makes distant markers inaccessible for producers, and situation in these markets - less competitive. Imperfect functioning of organizations that have to provide information to participants of local markets, lack of reliable information sources causes insufficient awareness of market participants, first of all, of prices in other places of agreements' conclusion.

It should be noted that investing money in technical assets, infrastructural agents strive to get some return. High share of incomes of mediatory and infrastructural elements in prices of agricultural production sales can be determined both their abuse of monopoly power in terms of insufficient competitiveness of market environment and actually high expenses for maintenance of technical assets. Insufficient demand for their services does not allow them obtaining a positive return from scale and expanding volumes of offer of services with simultaneous decreasing in expenses per unit and decreasing in prices for services.

Optimizing government regulation of the system of local markets, we are facing a complex problem of choice of a criterion that will allow diagnosing the abuse a mediatory and infrastructural organizations of their market power at the macro level and formation of a method of revealing such abuses not relating to separate subject of abuse, not by lodging of "injured" counterparts (it is possible only concerning a processing company - direct buying), but by the characteristics of a set of market agreements.

\section{Development of the system of local agricultural markets}

The fourth question of methodology of research of the system of local agricultural markets concerns its development. An aspect of development envisages revealing of internal conflicts of the system and research of such its states as growth, evolution, development. A feature of development of the system of local agricultural markets should be considered as the increase in volumes of agreements concluded in competitive conditions with simultaneous decrease in prices' volatility and growth of the levels of efficiency of economic activity of direct manufacturers of agricultural production and satisfaction of its consumers' needs. Phenomena and processes, which deprecate achieving stated orientations, should be considered as contradictions to the development of the system of local agricultural markets.
The main directions of the state regulatory influence on the development of the system of local agriculture market are: firstly, measures of the government regulation can be realized by means of compulsion of separate subjects to direct functioning of the system towards its more sustainable functioning; another direction envisages the state stimulation of formation of inverse relationships, which will ensure self-organization of the system. When choosing measures of the government regulation, we have to understand that economic agents remain independent economic entities and the state in most cases is not able to command what to do, how and for whom. We can choose only measures, which will be positively understood by independent entities.

\section{Measures on functioning and development of the system of local agricultural markets}

A systematized list of regulatory measures aimed at overcoming disadvantages in the functioning and development of the system of local agricultural markets stipulates the following:

1) for better consumers' needs satisfaction, prevention of breaking of good quality goods markets it is necessary to perfect a system of certification and control over the product quality, improve awareness of buyers, develop infrastructure of markets, as well as take measures for increasing quality product homogeneity within goods items;

2 ) in order to increase of efficiency of agricultural production sales by direct manufacturers it is necessary to inspire them to form large goods items of production, which is homogeneous by quality, inform about requirements for the quality and consumer needs, as well as development of transport infrastructure, approaching of places of conclusion of agreements to producers;

3) for decreasing volatility of prices there are needed measures toward the promotion of long-term contracting and improvement of informational support of participants of marketing agreements;

4) complex solution of the problem of development of infrastructural component of the system of markets, expanding of the network of trading areas require implementation of program measures, development of general plans of territories' development, encouragement of creation of specialized procurement terminals in order to form homogeneous wholesale consignments;

5) for prevention of misuse of market power, countermeasures for collusion of intermediate sellers and overcoming barriers that obstruct direct manufacturers to enter the markets of agricultural production, there is required a stimulation of creation of agricultural producers' associations and cooperative associations, which will oppose their monopoly power to power of intermediate sellers; 
6) increase in efficiency of the whole complex of state regulatory actions needs reforming of management subsystem of the system of local agricultural markets, introduction of state programming, optimization of relations between the national and regional levels of this sphere's regulation, improvement of informational support for processes of development and implementation of management actions.

\section{Conclusions and prospect of further research}

Thus, the formed theoretical and methodological foundations of analysis of the system of local agricultural markets will ensure efficiency of their functioning. The proposed step-by-step research of object as a system will allow determining clearly its structure, including materialized and non-materialized elements, controlled elements and elements, which are unaffected by managerial influence from the direction of government authorities, identifying relations among these elements. The use of method of opposition in a way "as it should be" and "as it can be" will allow foreseeing possible gaps in functioning of certain elements of the system of local markets, which determine disadvantages of the whole system, and also identifying their causes. Studying the system of local agricultural markets in terms of its development, namely focusing on contradictions of development, will allow revealing problems in the self-organization of the system of markets that can lead to the disruption of economic potentials of market participants, their incapability to perform main functions. Prospects of further research are the development of innovative models of functioning of the system of local agricultural markets.

\section{References}

About State Support of Agriculture of Ukraine (Law of Ukraine on June 24, 2004). Supreme Council of Ukraine [Pro derzhavnu pidtrimku silskogo gospodarstva Ukrayini: Zakon Ukrayini vid 24 chervnya 2004 r.]. Supreme Council of Ukraine, Vol. 49, Art. 527 (as amended).

About wholesale markets of agricultural products: the Law of Ukraine on June 25, 2009 [Pro optovi rinki silskogospodarskoyi produktsiyi: Zakon UkraYini vid 25 chervnya 2009 r.]. Official Bulletin of Ukraine, Vol. 58, Art. 20-24.

Belyaev, V.I. Local markets: their role, place and importance in the development of reproductive processes in the regions [Lokalnyie ryinki: ih rol, mesto i znachenie $\mathrm{v}$ razvitii vosproizvodstvennyih protsessov $\mathrm{v}$ regionah]. Retrieved from: http://izvestia.asu.ru/2012/2-1/econ/TheNewsOfASU-2012-2-1-econ-01.pdf.

Dubrovin, I. \& Belov, E. (2011). Evaluation of resource potential of the local market (for example meat) [Otsenka resursnogo potentsiala lokalnogo ryinka (na primere myasoproduktov)]. Logistics, Vol. 6, p. 48-49.

North, D. (1997). Institutions, Institutional Change and Functioning of the economy [Institutyi, institutsionalnyie izmeneniya i funktsionirovanie ekonomiki] (Nesterenko, A.N. transl. from English). Moscow: Fund economic book "Beginning", $180 \mathrm{p}$.

Regulation on Department of Strategy and Economic Development of Ministry of Agrarian Policy and Food of Ukraine, approved by the Ministry of Agrarian Policy and Food of Ukraine in April 6, 2016 N 130 [Polozhennya pro departament strategiyi ta ekonomichnogo rozvitku MInIsterstva agrarnoyi politiki ta prodovolstva Ukrayini: Zatverdzheno Nakazom Ministerstva agrarnoyi politiki ta prodovolstva Ukrayini 06 kvitnya 2016 roku N 130]. Retrieved from: http://cct.com.ua/2016/06.04.2016_130.htm.

Stupnikova, A.V. (2013). Theoretical aspects of the formation and functioning of local markets [Teoreticheskie aspektyi formirovaniya i funktsionirovaniya lokalnyih ryinkov]. Problems of modern economy, Vol. 2, issue 46, p. 70-72.

The main priorities of the Common Agricultural Policy (CAP) of the EU [Osnovni prioriteti spilnoyi agrarnoyi politiki (SAP) krayin ES]. Retrieved from: http://www.amdi.org.ua/home/amdi-news/300-the-.html.

The only comprehensive strategy and action of plan for the development of agriculture and rural areas in Ukraine for 2015-2020 [The only comprehensive strategy and action of plan for the development of agriculture and rural

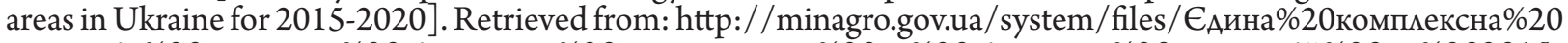
стратегія\% 20 розвитку\% 20 сільського 20 господарства $\% 20$ та\% 20 сільських $\% 20$ територій\% 20 на $\% 202015$ 2020.pdf.

Tsvetkova, G.S. (2010). To a question about the positioning of the local market [K voprosu o pozitsionirovanii lokalnogo ryinka]. Vestnik OSU, Vol. 8, issue 114, p. 148-153. 
Vol. 2, No. 5, 2016

Baltic Journal of Economic Studies

\section{Юрий ПРУДНИКОВ}

\section{ФУНКЦИОНИРОВАНИЕ СИСТЕМЫ ЛОКАЛЬНЫХ СЕЛЬСКОХОЗЯЙСТВЕННЫХ РЫНКОВ:} ИНСТИТУЦИОНАЛЬНЫЕ АСПЕКТЫ

Аннотация. Целью данной статьи является обобщение и систематизация особенностей современного институционального обеспечения функционирования и развития системы локальных рынков сельскохозяйственной продукции. Методологию исследования сформирована на системном подходе к изучению социально-экономических явлений и процессов, происходящих в процессе функционирования и развитиясистемылокальныхрынковсельскохозяйственнойпродукции.Результатыисследования-наоснове системного анализа обоснованы особенности функционирования и развития системы локальных рынков сельскохозяйственной продукции с позиции ее институционального обеспечения. Указанное осуществлено с целью определения целесообразности, целевой ориентации, объемов, целей и задач государственного вмешательства в процесс функционирования и развития системы локальных рынков сельскохозяйственной продукции. Приложив общую схему системного анализа системы управления локальными рынками сельскохозяйственной продукции и учтя, что система управления состоит из двух подсистем - управляющей и управляемой, в контексте данного исследования осуществлен характеристику системы в форме ответов на определенный перечень вопросов. Содержание разработанного теоретико-методологического подхода заключается в разработке обоснованных ответов на четыре ключевых вопроса, характерны и релевантно размещены для каждого этапа проведения исследования: 1) определение элементов внутренней и внешней среды, которые входят в состав системы локальных рынков сельскохозяйственной продукции; 2) характеристика отношений и связей между выявленными элементами системы; 3) собственно процесс функционирования системы локальных рынков сельскохозяйственной продукции; 4) особенности развития системы локальных рынков сельскохозяйственной продукции. Разработаны меры регулятивного характера, направленные на преодоление идентифицированных недостатков в функционировании и развитии системы локальных рынков сельскохозяйственной продукции, направляются на: удовлетворение потребностей целевых потребителей сельскохозяйственной продукции и повышение качественной однородности продукции в рамках товарных партий; повышение эффективности реализации сельскохозяйственной продукции ее непосредственными производителями, формирование логистической ситсеми; снижение волатильности цен; комплексного решения проблемы развития инфраструктурного компонента системы рынков, расширение сети торговых площадок, предотвращения злоупотреблений рыночной властью, противодействия сговоре между посредниками и преодоления барьеров, препятствующих выходу непосредственных производителей на рынки сельскохозяйственной продукции, повышение эффективности всего комплекса государственных регулирующих мероприятий. Практическое значение результатов исследования заключается в том, что сформированы теоретико-методические основы системного анализа функционирования и развития системы локальных рынков сельскохозяйственной продукции с позиции ее институционального обеспечения сделают возможным ее эффективное функционирование и развитие. 